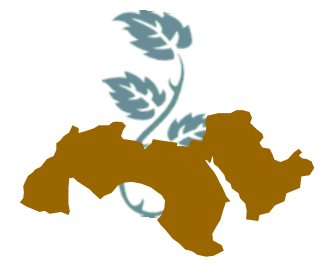

\title{
EFFECT OF PRUNNING PATTERN AND SOIL MULCHING ON YIELD AND QUALITY OF KEITT MANGO IN NEW RECLAIMED LANDS
}

\author{
Salama, B.L.; A.F. Abou-Hadid; N. Abdelhamid and M.Z. El-Shinawy \\ Horticulture Dept., Fac. of Agric., Ain Shams Univ., Cairo, Egypt
}

Keywords: pruning, soil mulching, yield, quality, kitt mango cv., leaf mineral content

\section{ABSTRACT}

The present study was carried out during 2014 and 2015 seasons on adult Kitt Mango Trees to evaluate 4 levels of pruning pattern (removing one-third, one-half, all branch or without pruning) and 4 types of soil mulching (white plastic, black plastic, rice straw or without soil mulching) on vegetative growth, leaf mineral content, flowering and yield.

Average shoot length, shoot thickness and average number of shoot / tree of Kitt mangos greatly affected with both pruning pattern and soil mulching, especially with removing of one-third of branch and covering soil with white plastic sheet.

However leaf $\mathrm{N}, \mathrm{P}$ and $\mathrm{K}$ contents were improved with both one-third and one-half pruning of branches of Kitt mango trees where both white and black plastic of mulch soil were similar in their effect on leaf NPK content.

There were an evident increase in fruit set \%, total yield ( $\mathrm{kg} /$ tree) and marketable yield \% with one-third and one-half pruning of branch and also with white and black plastic of soil mulching. The increase of marketable yield\% due to these treatments could be attributed to the increase of vegetative canopy of leaves which led to prevent sun burn of fruits and to minimize heat solar effect from the soil and protect the fruits in lower parts of the trees.

Fruit chemical constituents including TSS\%, acidity and L-ascorbic acid slightly affected with different treatments but one-third and one-half prunning of branch as well as with white and black plastic of soil mulch could be recommended as a good horticulture treatments in Kitt mango orchards

\section{INTRODUCTION}

The mango (Mangifera indica L.) belongs to the family Anacardiaceae، originally from southern Asia, more precisely from India, where it has been cultivated for more than 4,000 years from the Malay Islands. The number of species in the genus Mangifera is controversial. Mukherjee (1985) describes 35 species, while Bompard (1993) reported the existence of 69 species, with Mangifera indica as the most commercially important.

Mango fruits, are one of the most popular fruits in Egypt. It contains a high percent of sugars, protein, fats, mineral salts, vitamins $A, C, E$ and other $B$ vitamins and essential nutrients such as potassium, copper and 17 amino acids are at good levels, and it plays an important role in food industrialization such as juices, which wanted with large amounts to export according to good reputation of Egyptian varieties.

Now, the policy strategy of Egypt is to increase the quality level of exported crops to certain European countries, for this reason many efforts has been done to increase the total cultivated areas of mango in Egypt, as a favorable fruits in many countries. Mango trees were introduced to Egypt around 1825 and ever since it has gradually expanded throughout the country and became one of the main fruits which rank the third after Citrus and Grapes. The total acreage of mango in Egypt reached 265350 feddans in 2015, producing about 927352 tons. These area concentrate in Sharkia, Ismailia, Giza average $85 \%$ from production (Economic Agricultural Report (2015).

Mongo trees are one the most important fruit trees, which succeed under Upper Egypt conditions but high temperature degree increases evapotranspiration rate. Consequently, the amount of needed water by trees increases, especially at new 
reclaimed soils of low water supply. Due to high temperature of Egyptian region between (April and October) there exists very high water evaporation rate. Surface mulch (Mulch refers to material placed on soil surface) has a significant effect on reducing evaporation of water.

Mango orchard soils of Malihabad belt Uttar Pradesh are poor in soil organic matter and essential nutrients (Sangha et al 2012). Restoration of orchard soil is important and essential from view point of sustainability and orchard productivity (Tejada et al 2006). Soil rejuvenation with organic substrates is an important orchard ground floor management strategy to improve the health status of soil (Arancon et al 2006). Albiach et al (2000) observed that under conventional horticultural cropping, deterioration of soil physical, chemical and biological properties were related to various activities of continuous soil removal, tillage and intensive use of pesticides and fertilizers. Although mineral fertilization provides readily available nutrients for plant growth, it does not contribute to improve soil physical condition. Organic matter inputs through organic amendments, in addition to supplying nutrients, stimulate microbial diversity and activity and improved soil aggregation, which had positive effects on soil water content, temperature, aeration and mechanical impedance (Ferreras et al 2006).

Furthermore, there have been many reports that organic fertilizers can increase soil microbiological activity (Bulluck et al 2002) and many enzymatic activities have been reported to be correlated with total organic $\mathrm{C}$, soil moisture, temperature and organic sources (Bell et al 2008). The increase of dehydrogenase activity in organically treated soil may be attributed to intense activity of soil microorganisms in degrading easily metabolizable compounds, with subsequent decreases in activity, attributed to the decreases in quantities of easily biodegradable substances. Since enzymatic activity differs both at temporal and spatial scale within a filed level, it is important to understand the dynamics of its sctivity along with their correlation with other soil factors; of course, short-term or long-term orchard soil management had impact on soil processes (Singh et al 2011; Hazarika et al 2011; Singh et al 2012; Adak et al 2012 and Kumar et al 2012).

The main target of this study was to evaluate different pruning patterns and soil mulching types on yield and quality of Kitt mangos to maximize the marketable yield and minimize its losses

\section{MATERIALS AND METHODS}

This study was conducted during the seasons of 2014 and 2015 on mature Kitt mango trees in a private farm at Cairo - Alexandria desert road Egypt. The trees were 5 years of age at the beginning of the experiment and planted at $3 \times 3 \mathrm{~m} \mathrm{(460}$ trees / fed)under drip irrigation system, healthy, similar in growth and free from various injuries. All horticultural practices such as irrigation, fertilization, pest and diseases controls were applied. The experiment was designed in a complete randomized blocks. The following treatment was designed:

\section{Pruning pattern}

Four pruning patterns were done at September of the previous season, all pruning pattern were similar in quantity of removing tissues of all tree, pruning pattern were applied as follows:-

Removal of one-third of each branch length in the tree vegetation.

Removal of one-half of each branch length in the tree vegetation.

Removal of number of branches equal to onethird of tree vegetation.

Non-removal of any of the tree (without pruning) vegetation.

\section{Soil mulching}

Four soil mulching treatments were applied:-

1. Black plastic mulch (1 meter width and 60 microns in the thickness).

2. White plastic mulch ( 1 meter width and 60 microns in the thickness).

3. Rice straw mulch ( 1 meter width and of 2 $\mathrm{cm}$ in the thickness).

4. Without covering soil.

The different measurements were recorded during the two studied seasons on vegetative growth parameters, leaf mineral content of NPK ,fruit set ,total yield and marketable yield. Also fruit chemical constituents including TSS, acidity and Lascorbic acid were also determined.

\section{Vegetative growth parameters}

Four main branches which were nearly uniform in growth, diameter and foliage density and distribution around the periphery of each tree were chosen and labeled in March in each season, The following vegetative characters were measured in mid-September of each season: 
- Average spring shoot length $(\mathrm{cm})$

- Shoot thickness flush $(\mathrm{cm})$

- Average number of shoots / tree

Leaf mineral status $(\mathbf{N}, \mathbf{P}, \mathbf{K})$, to determine the leaf nutrient content, fifty mature leaves of a seven months age from the non-fruiting shoots of the spring flush were randomly taken from each replication in mid-September. The leaf samples were washed with tap water and distilled water, air dried, oven - dried at $70 \cong \mathrm{C}$ till constant weight, and ground in a stainless steel mill and kept for chemical analysis (Nijjar, 1985). One part of ground sample was analyzed for total nitrogen by the semi-microkjaldahl technique (Bremner and Mulvaney, 1982 and Wilde et al 1985). Another part of each ground dried leaf sample was wet - digested with conc. Sulfuric acid and $30 \%$ hydrogen peroxide according to the method described by Evenhuis and Dewaard (1980). Phosphorus and potassium in the digest were determined by colorimetric and flame photometry methods respectively. Data of NPK was expressed as g $/ 100 \mathrm{~g}$ dry weight (\%).

\section{Fruit set, total yield and marketable yield}

- Fruit set (\%): At flowering time (March) of both seasons; ten branches representing all sides of each experimental tree were chosen and labeled before the beginning of treatments. During both experimental seasons the percentage of setted fruits were calculated (one month from full bloom) according to the following formula: Fruit set $\%=$ (total number of set fruits $/$ total number of flowers at full bloom) $\times 100$

- Total Yield kg / tree: Fruits were harvested at suitable maturity indices in the two successive years at mid-September. Total yield as $\mathrm{kg} /$ tree was determined.

- Marketable yield: fruits with any disorders especially splitting and sun scald were counted and discarded and marketable yield (fruit with good quality) was calculated.

\section{Chemical fruit constituents}

- TSS, and TA: Digital refractometer (Atago, RS5000, Atago, Japan) was used to determine TSS $\%$ of fruit juice. TA was expressed as percent citric acid / $100 \mathrm{~g}$ fruit flesh. (A.O.A.C 1980)
- Ascorbic acid: Ascorbic acid contents of juice were determined following the method described by Ruck (1969). Ten $\mathrm{mL}$ of juice was taken in a $100 \mathrm{~mL}$ volumetric flask and volume was made by adding $0.4 \%$ oxalic acid solution. Five $\mathrm{mL}$ filtrated aliquot was titrated against 2 , 6- dichlorophenolindophenol dye, to light pink colour end point (persisted at least for $15 \mathrm{sec}$ onds). The ascorbic acid contents were expressed as $\mathrm{mg} / 100 \mathrm{~g}$ fruit flesh.

\section{Statistical analysis}

All the obtained data were tabulated and statistically analyzed according to (Snedecor and Cocharn, 1980) using new L.S.R at $5 \%$ level for selecting the significant differences among treatment means

\section{RESULTS AND DISCUSSION}

Vegetative growth parameters

\section{Average shoot length $(\mathrm{cm})$}

Data tabulated in Table (1) show the effect of different models of pruning pattern and different type soil mulching for spring shoot length on Kitt Mango Tree during 2014 and 2015 seasons.

For Kitt mango trees, which were trimmed by removing one third of the branches, gave the highest values of branch length of than those that were trimmed by removing half the branches or remove the whole branches with significant differences between them in the two seasons of the study.

In the case of white plastic coverage, the mango trees were superior to the length of the branch than those covered by black or straw plastics, with clear moral differences between the three rates.

The highest interaction values for the length of the branch was with the level of trimming one third of the branch with white plastic coverage and the lowest values with the removal of the whole branch and without coverage.

\section{Shoot thickness (cm)}

Data tabulated in Table (2) show the effect of different models of pruning pattern and different type of coverage soil mulching for spring shoot thickness on Kitt Mango trees during 2014 and 2015 seasons. 
Table 1. Effect of pruning pattern and soil mulching type on Shoot length flush $(\mathrm{cm})$ of Kitt mango Trees during 2014 and 2015 seasons.

\begin{tabular}{|c|c|c|c|c|c|}
\hline \multirow{3}{*}{ Pruning Treatments } & \multicolumn{4}{|c|}{ Season 2014} & \multirow{3}{*}{ Mean } \\
\hline & \multicolumn{4}{|c|}{ Soil mulching type } & \\
\hline & Without & Black & White & Rice Straw & \\
\hline Non-pruning(control) & $37.2 \mathrm{de}$ & $36.4 \mathrm{e}$ & $39.7 c-e$ & $39.2 \mathrm{c}-\mathrm{e}$ & 38.13B \\
\hline one-third removal & $41.5 b-d$ & $42.9 b c$ & $49.1 \mathrm{a}$ & 46.3ab & 44.95A \\
\hline one-half removal & $40.3 \mathrm{c}-\mathrm{e}$ & $43.7 \mathrm{bc}$ & $48.4 \mathrm{a}$ & $44.9 a b$ & $44.32 \mathrm{~A}$ \\
\hline Whole branch removal & $35.7 \mathrm{e}$ & $38.8 \mathrm{e}$ & $38.5 c-e$ & 37.7de & $36.92 \mathrm{C}$ \\
\hline Mean & $38.38 \mathrm{C}$ & $39.7 \mathrm{C}$ & 43.9A & 42.0B & \\
\hline \multicolumn{6}{|c|}{ Season 2015} \\
\hline Non-pruning(control) & 36.9 de & 38.2 de & $40.5 \mathrm{~cd}$ & 38.9 c-e & $38.38 \mathrm{C}$ \\
\hline one-third removal & $40.5 \mathrm{~cd}$ & $43.8 \mathrm{bc}$ & $50.4 \mathrm{a}$ & $47.7 \mathrm{a}$ & $45.6 \mathrm{~A}$ \\
\hline one-half removal & $37.9 \mathrm{c}-\mathrm{e}$ & $40.8 \mathrm{~cd}$ & $47.4 \mathrm{ab}$ & $45.3 \mathrm{ab}$ & 42.85 B \\
\hline Whole branch removal & $34.2 \mathrm{e}$ & 36.9 de & $38.3 \mathrm{c}-\mathrm{e}$ & 35.4 de & $36.2 \mathrm{D}$ \\
\hline Mean & 37.38 D & $39.68 \mathrm{C}$ & $44.15 \mathrm{~A}$ & $41.9 \mathrm{~B}$ & \\
\hline
\end{tabular}

Values followed by the same letter (s) are not significantly different at $5 \%$ level

Table 2. Effect of pruning pattern and soil mulching type on Shoot thickness flush $(\mathrm{cm})$ Of Kitt Mango tree during 2014 and 2015 seasons

\begin{tabular}{|c|c|c|c|c|c|}
\hline \multirow{3}{*}{ Pruning Treatments } & \multirow{2}{*}{\multicolumn{4}{|c|}{$\begin{array}{c}\text { Season } 2014 \\
\text { Soil mulching type }\end{array}$}} & \multirow{3}{*}{ Mean } \\
\hline & & & & & \\
\hline & Without & Black & White & Rice Straw & \\
\hline Non-pruning(control) & $0.37 \mathrm{~d}$ & $0.80 \mathrm{~b}-\mathrm{d}$ & $0.87 \mathrm{a}-\mathrm{c}$ & $0.84 \mathrm{bc}$ & $0.81 B$ \\
\hline one-third removal & $0.85 a-c$ & $0.87 \mathrm{a}-\mathrm{c}$ & $0.94 \mathrm{a}$ & $0.91 \mathrm{ab}$ & $0.88 \mathrm{~A}$ \\
\hline one-half removal & $0.83 d$ & $0.85 a-c$ & $0.9 \mathrm{ab}$ & $0.88 \mathrm{a}-\mathrm{c}$ & $0.87 \mathrm{~A}$ \\
\hline Whole branch removal & $0.7 \mathrm{~d}$ & $0.78 \mathrm{~cd}$ & $0.79 \mathrm{~cd}$ & $0.8 \mathrm{~b}-\mathrm{d}$ & 0.77 B \\
\hline Mean & $0.78 \mathrm{~B}$ & $0.83 \mathrm{AB}$ & $0.88 \mathrm{~A}$ & $0.86 \mathrm{~A}$ & \\
\hline \multicolumn{6}{|c|}{ Season 2015} \\
\hline Non-pruning(control) & $0.74 d$ & $0.82 b-d$ & $0.86 a-c$ & $0.82 b-d$ & $0.86 \mathrm{~B}$ \\
\hline one-third removal & $0.87 \mathrm{a}-\mathrm{c}$ & $0.90 \mathrm{ab}$ & $0.96 \mathrm{a}$ & $0.94 \mathrm{a}$ & $0.92 \mathrm{~A}$ \\
\hline one-half removal & $0.86 a-c$ & $0.87 \mathrm{a}-\mathrm{c}$ & $091 \mathrm{ab}$ & $0.89 a-c$ & $0.88 \mathrm{AB}$ \\
\hline Whole branch removal & $0.73 d$ & $0.80 \mathrm{~cd}$ & $0.81 \mathrm{bcd}$ & $0.80 \mathrm{~cd}$ & $0.79 \mathrm{C}$ \\
\hline Mean & $0.80 \mathrm{~B}$ & $0.85 \mathrm{AB}$ & $0.89 \mathrm{~A}$ & $0.86 \mathrm{~A}$ & \\
\hline
\end{tabular}

Values followed by the same letter (s) are not significantly different at $5 \%$ level 
High values of fish branch recorded with the Kitt mango trees that was trimmed by removing one third of the branches from those that were trimmed by removing half of the branches or remove the whole branch with significant differences between them.

Kitt mango trees that were covered with plastic White was superior in the thickness of the branch from those that have been covered black plastic or straw with significant differences apparent between the three rates.
The highest values for interaction was trim third section with a white plastic cover and lower values with the removal of entire branches with no coverage.

\section{Number of shoot/ tree}

Data tabulated in Table (3) show the effect of different models of pruning and different type of coverage for number of shoot/ tree on Kitt Mango Tree during 2014 and 2015 seasons.

Table 3. Effect of pruning pattern and soil mulching type on number of shoot/ tree of Kitt Mango trees during 2014 and 2015 seasons.

\begin{tabular}{|c|c|c|c|c|c|}
\hline \multirow{3}{*}{ Pruning Treatments } & \multirow{2}{*}{\multicolumn{4}{|c|}{$\begin{array}{c}\text { Season } 2014 \\
\text { Soil mulching type }\end{array}$}} & \multirow{3}{*}{ Mean } \\
\hline & & & & & \\
\hline & Without & Black & White & Rice Straw & \\
\hline $\begin{array}{l}\text { Non-pruning(control) } \\
\text { one-third removal } \\
\text { one-half removal } \\
\text { Whole branch removal }\end{array}$ & $\begin{array}{c}32.1 \mathrm{e} \\
38.8 \mathrm{~cd} \\
35.4 \mathrm{de} \\
32.7 \mathrm{e}\end{array}$ & $\begin{array}{l}34.9 \mathrm{de} \\
40.9 \mathrm{bc} \\
37.2 \mathrm{~cd} \\
32.7 \mathrm{e}\end{array}$ & $\begin{array}{c}35.7 \mathrm{de} \\
45.7 \mathrm{a} \\
42.9 \mathrm{ab} \\
33.9 \mathrm{de}\end{array}$ & $\begin{array}{l}33.6 \mathrm{de} \\
43.5 \mathrm{ab} \\
40.5 \mathrm{bc} \\
32.7 \mathrm{e}\end{array}$ & $\begin{array}{l}34.08 \mathrm{C} \\
41.73 \mathrm{~A} \\
39.0 \mathrm{~B} \\
32.5 \mathrm{C}\end{array}$ \\
\hline Mean & $33.7 \mathrm{C}$ & $36.43 \mathrm{~B}$ & $39.55 \mathrm{~A}$ & $37.6 \mathrm{AB}$ & \\
\hline \multicolumn{6}{|c|}{ Season 2015} \\
\hline $\begin{array}{l}\text { Non-pruning(control) } \\
\text { one-third removal } \\
\text { one-half removal } \\
\text { Whole branch removal }\end{array}$ & $\begin{array}{c}30.8 \mathrm{f} \\
37.3 \mathrm{~cd} \\
36.8 \mathrm{de} \\
30.9 \mathrm{f}\end{array}$ & $\begin{array}{l}36.7 \mathrm{de} \\
41.7 \mathrm{bc} \\
41.1 \mathrm{bc} \\
33.2\end{array}$ & $\begin{array}{c}39.6 \mathrm{~cd} \\
47.1 \mathrm{a} \\
44.8 \mathrm{ab} \\
36.8 \mathrm{de}\end{array}$ & $\begin{array}{l}38.4 \mathrm{~cd} \\
45.6 \mathrm{a} \\
43.5 \mathrm{ab} \\
34.7 \mathrm{e}\end{array}$ & $\begin{array}{l}36.38 \mathrm{~B} \\
42.93 \mathrm{~A} \\
41.55 \mathrm{~A} \\
34.15 \mathrm{~B}\end{array}$ \\
\hline Mean & $33.95 \mathrm{C}$ & $38.18 \mathrm{~B}$ & $42.08 \mathrm{~A}$ & $40.8 \mathrm{~A}$ & \\
\hline
\end{tabular}

Values followed by the same letter (s) are not significantly different at $5 \%$ level

Kitt mango trees trimmed by removing one third of the branches the highest values of the number of branches than those that were trimmed gave by removing half the branches or removing the entire branches during the two seasons of the study with significant differences between them. When covering the soil with white plastic, the Kitt mango trees surpassed those covered by black plastic and the leaves with significant differences between the three types. The highest values of the interaction of the number of branches on the tree was with the level of trimming one third of the branch with the coverage of white plastic and the lowest values with the removal of the entire branches covered with black plastic.

The results were in agreements with those obtained by Gaikwad (2004) on Nagpur mandarin, Abdel-Aziz et al (2010) on Valencia orange trees under Toshka conditions and Mikhael (2007) on "Anna" apple trees grown in loamy sand soil at ElBostan region, El-Beheira Governorate.

\section{Leaf mineral contents}

Leaf nitrogen \% (N\%)

Data tabulated in Table (4) show the effect of different models of pruning and different type of coverage for Leaf nitrogen \% (N\%) on Kitt Mango Tree during 2014 and 2015 seasons.

There were no significant differences for Kitt mango trees been remove third branches has to remove half of the entire Branch branches in influencing the content of nitrogen in the paper Kitt mango trees during the seasons.

There was a significant effect of Kitt mango trees has covered the White plastic was superior in the content of the nitrogen from those that have been covered with black plastic with a significant difference clear between them leaf

The highest values for interaction along with the level of pruning was trim third branches with a white plastic cover and lower values with the removal of entire branches with no coverage. 
Table 4. Effect of pruning pattern and soil mulching type on leaves $\mathrm{N} \%$ of Kitt Mango Trees during 2014 and 2015 seasons.

\begin{tabular}{|c|c|c|c|c|c|}
\hline \multirow{3}{*}{ Pruning Treatments } & \multicolumn{4}{|c|}{ Season 2014} & \multirow[t]{3}{*}{ Mean } \\
\hline & \multicolumn{4}{|c|}{ Soil mulching type } & \\
\hline & Without & Black & White & Rice Straw & \\
\hline $\begin{array}{l}\text { Non-pruning(control) } \\
\text { one-third removal } \\
\text { one-half removal } \\
\text { Whole branch removal } \\
\text { Mean }\end{array}$ & $\begin{array}{c}1.62 \mathrm{~d} \\
1.73 \mathrm{bc} \\
1.69 \mathrm{~cd} \\
1.6 \mathrm{~d} \\
\mathbf{1 . 6 6 ~ B}\end{array}$ & $\begin{array}{l}1.7 \mathrm{~b}-\mathrm{d} \\
1.8 \mathrm{ab} \\
1.77 \mathrm{bc} \\
1.67 \mathrm{~cd} \\
\mathbf{1 . 7 4 A B}\end{array}$ & $\begin{array}{l}1.73 \mathrm{bc} \\
1.91 \mathrm{a} \\
1.8 \mathrm{ab} \\
1.69 \mathrm{~cd} \\
\mathbf{1 . 7 8 ~ A}\end{array}$ & $\begin{array}{l}1.71 \mathrm{~b}-\mathrm{d} \\
1.92 \mathrm{a} \\
1.86 \mathrm{a} \\
1.7 \mathrm{~b}-\mathrm{d} \\
\mathbf{1 . 8} \mathrm{A}\end{array}$ & $\begin{array}{l}1.69 \mathrm{BC} \\
1.84 \mathrm{~A} \\
1.78 \mathrm{~B} \\
1.67 \mathrm{C}\end{array}$ \\
\hline \multicolumn{6}{|c|}{ Season 2015} \\
\hline $\begin{array}{l}\text { Non-pruning(control) } \\
\text { one-third removal } \\
\text { one-half removal } \\
\text { Whole branch removal }\end{array}$ & $\begin{array}{l}1.63 \mathrm{~d} \\
1.72 \mathrm{~cd} \\
1.7 \mathrm{~cd} \\
1.65 \mathrm{~d}\end{array}$ & $\begin{array}{l}1.77 \mathrm{bc} \\
1.87 \mathrm{ab} \\
1.82 \mathrm{ab} \\
1.72 \mathrm{~cd}\end{array}$ & $\begin{array}{l}1.75 \mathrm{bc} \\
1.95 \mathrm{a} \\
1.91 \mathrm{a} \\
1.69 \mathrm{~cd}\end{array}$ & $\begin{array}{c}1.73 \mathrm{~cd} \\
1.9 \mathrm{a} \\
1.85 \mathrm{ab} \\
1.72 \mathrm{~cd}\end{array}$ & $\begin{array}{l}1.72 \mathrm{~B} \\
1.86 \mathrm{~A} \\
1.81 \mathrm{~A} \\
1.69 \mathrm{~B}\end{array}$ \\
\hline Mean & $1.68 \mathrm{~B}$ & $1.8 \mathrm{~A}$ & $1.83 \mathrm{~A}$ & $1.8 \mathrm{~A}$ & \\
\hline
\end{tabular}

Values followed by the same letter (s) are not significantly different at $5 \%$ level

\section{Leaf Phosphorus \%}

Data tabulated in Table (5) show the effect of different models of pruning and different type of coverage for Leaf Phosphorus\% on Kitt Mango Tree during 2014 and 2015 seasons.

There were no significant differences for Kitt mango trees been to remove a third of branches, which has to remove half of the branch entire branches to influence the content of the leaf $P$ in the Kitt mango trees through the seasons.
There was for Kitt mango trees has covered the White plastic was superior in leaf content of phosphorus from those that have been covered with plastic black on with a significant difference between them the pruning.

The highest values for interaction along with the level of the branches was trim third section with a white plastic cover and lower values with the removal of entire branches with no coverage.

Table 5. Effect of pruning pattern and soil mulching type on leaves P\% of Kitt Mango Trees during 2014 and 2015 seasons.

\begin{tabular}{|c|c|c|c|c|c|}
\hline \multirow{3}{*}{ Pruning Treatments } & \multicolumn{4}{|c|}{ Season 2014} & \multirow{3}{*}{ Mean } \\
\hline & \multicolumn{4}{|c|}{ Soil mulching type } & \\
\hline & Without & Black & White & Rice Straw & \\
\hline $\begin{array}{l}\text { Non-pruning(control) } \\
\text { one-third removal } \\
\text { one-half removal } \\
\text { Whole branch removal }\end{array}$ & $\begin{array}{c}0.19 \mathrm{~cd} \\
0.2 \mathrm{~cd} \\
0.23 \mathrm{~b}-\mathrm{d} \\
0.17 \mathrm{~d}\end{array}$ & $\begin{array}{c}0.23 \mathrm{~b}-\mathrm{d} \\
0.27 \mathrm{ab} \\
0.26 \mathrm{ab} \\
0.2 \mathrm{~cd}\end{array}$ & $\begin{array}{c}0.24 \mathrm{~b}-\mathrm{d} \\
0.29 \mathrm{a} \\
0.27 \mathrm{ab} \\
0.23 \mathrm{~b}-\mathrm{d}\end{array}$ & $\begin{array}{c}0.26 \mathrm{ab} \\
0.28 \mathrm{a} \\
0.27 \mathrm{ab} \\
0.25 \mathrm{~b}\end{array}$ & $\begin{array}{l}0.23 \mathrm{AB} \\
0.26 \mathrm{~A} \\
0.26 \mathrm{~A} \\
0.21 \mathrm{~B}\end{array}$ \\
\hline Mean & $0.2 \mathrm{~B}$ & $0.2 \mathrm{~B}$ & $0.26 \mathrm{~A}$ & $0.27 \mathrm{~A}$ & \\
\hline \multicolumn{6}{|c|}{ Season 2015} \\
\hline $\begin{array}{l}\text { Non-pruning(control) } \\
\text { one-third removal } \\
\text { one-half removal } \\
\text { Whole branch removal }\end{array}$ & $\begin{array}{l}0.18 c \\
0.2 c \\
0.2 c \\
0.19 c\end{array}$ & $\begin{array}{c}0.23 \mathrm{bc} \\
0.27 \mathrm{ab} \\
0.23 \mathrm{bc} \\
0.19 \mathrm{c}\end{array}$ & $\begin{array}{l}0.25 \mathrm{ab} \\
0.31 \mathrm{a} \\
0.28 \mathrm{a} \\
0.21 \mathrm{c}\end{array}$ & $\begin{array}{c}0.21 \mathrm{c} \\
0.29 \mathrm{a} \\
0.28 \mathrm{a} \\
0.22 \mathrm{bc}\end{array}$ & $\begin{array}{c}0.22 A B \\
0.26 A \\
0.24 A B \\
0.2 \mathrm{~B}\end{array}$ \\
\hline Mean & $0.19 B$ & $0.23 A B$ & $0.26 \mathrm{~A}$ & $0.25 \mathrm{~A}$ & \\
\hline
\end{tabular}

Values followed by the same letter (s) are not significantly different at $5 \%$ level 


\section{Leaf potassium (K\%)}

Data tabulated in Table (6) show the effect of different models of pruning and different type of coverage for Leaf potassium (K\%) on Kitt Mango Tree during 2014 and 2015 seasons.

There were no significant differences for Kitt mango trees been to remove a third of branches, which has to remove half of the branch entire branches to influence the content of leaf potassium in the Mango Trees Kitt through the seasons.

For Kitt mango trees has covered the White plastic or straw was the content of the leaf of po- tassium there is no significant difference between them and clear through the seasons.

The highest values for interaction along with the level of the section was trim third section with a white plastic cover and lower values with the removal of entire branches with no coverage.

The results were in agreements with those obtained by Dutta et al (2010). on effect of different sources of potassium on yield, quality, and leaf mineral content of mango in West Bengal and Tomas et al (2012). minerals and metal content of four mango (Mangifera indica L.) cultivar leaves grown in South Florida, Poster Board.

Table 6. Effect of pruning pattern and soil mulching type on leaves $\mathrm{K} \%$ of Kitt Mango Trees during 2014 and 2015 seasons.

\begin{tabular}{|c|c|c|c|c|c|}
\hline \multirow{3}{*}{ Pruning Treatments } & \multicolumn{4}{|c|}{ Season 2014} & \multirow{3}{*}{ Mean } \\
\hline & \multicolumn{4}{|c|}{ Soil mulching type } & \\
\hline & Without & Black & White & Rice Straw & \\
\hline Non-pruning(control) & $1.43 \mathrm{ab}$ & $1.5 \mathrm{ab}$ & $1.54 \mathrm{ab}$ & $1.55 \mathrm{ab}$ & $1.51 \mathrm{AB}$ \\
\hline one-third removal & $1.56 \mathrm{ab}$ & $1.67 \mathrm{ab}$ & $1.73 \mathrm{a}$ & $1.7 \mathrm{a}$ & $1.67 \mathrm{~A}$ \\
\hline one-half removal & $1.5 \mathrm{ab}$ & $1.53 a b$ & $1.67 \mathrm{ab}$ & $1.68 \mathrm{ab}$ & $1.6 \mathrm{AB}$ \\
\hline Whole branch removal & $1.45 \mathrm{ab}$ & $1.4 \mathrm{~b}$ & $1.47 \mathrm{ab}$ & $1.5 \mathrm{ab}$ & $1.46 \mathrm{~B}$ \\
\hline Mean & $1.49 \mathrm{~A}$ & $1.53 \mathrm{~A}$ & $1.6 \mathrm{~A}$ & $1.61 \mathrm{~A}$ & \\
\hline \multicolumn{6}{|c|}{ Season 2015} \\
\hline Non-pruning(control) & $1051 \mathrm{a}$ & $1.5 \mathrm{a}$ & $1.55 \mathrm{a}$ & $1.53 \mathrm{a}$ & $1.52 \mathrm{~A}$ \\
\hline one-third removal & $1.49 \mathrm{a}$ & $1.67 \mathrm{a}$ & $1.71 \mathrm{a}$ & $1.74 \mathrm{a}$ & $1.65 \mathrm{~A}$ \\
\hline one-half removal & $1.54 \mathrm{a}$ & $1.6 \mathrm{a}$ & $1.67 \mathrm{a}$ & $1.7 \mathrm{a}$ & $1.63 \mathrm{~A}$ \\
\hline Whole branch removal & $1.44 a$ & $1.49 \mathrm{a}$ & $1.51 \mathrm{a}$ & $1.52 \mathrm{a}$ & $1.49 \mathrm{~A}$ \\
\hline Mean & $1.5 \mathrm{~A}$ & $1.67 \mathrm{~A}$ & $1.61 \mathrm{~A}$ & $1.62 \mathrm{~A}$ & \\
\hline
\end{tabular}

Values followed by the same letter (s) are not significantly different at $5 \%$ level

\section{Fruit set and Total yield}

\section{Fruit set \%}

Data tabulated in Table (7) show the effect of different models of pruning and different type of coverage for levels on Final fruit set \% on Kitt Mango Tree during 2014 and 2015 seasons.

The proportion of the final contract for Mango Trees Kitt which has been the removal of one-third of branches, which has to remove half of the branch entire branches with a significant difference through the seasons.

Increase the proportion of the final contract with the presence of significant differences for Mango Trees Kitt has covered the White plastic or straw through the seasons.

The highest values for interaction along with the level of the section was trim third section with a white plastic cover and lower values with the removal of entire branches with no coverage. 
Table 7. Effect of pruning pattern and soil mulching type on Final fruit set of Kitt Mango Trees during 2014 and 2015 seasons.

\begin{tabular}{|c|c|c|c|c|c|}
\hline \multirow{3}{*}{ Pruning Treatments } & \multicolumn{4}{|c|}{ Season 2014} & \multirow[t]{3}{*}{ Mean } \\
\hline & \multicolumn{4}{|c|}{ Soil mulching type } & \\
\hline & Without & Black & White & Rice Straw & \\
\hline $\begin{array}{l}\text { Non-pruning(control) } \\
\text { one-third removal } \\
\text { one-half removal } \\
\text { Whole branch removal }\end{array}$ & $\begin{array}{c}1.5 \mathrm{e} \\
1.81 \mathrm{c}-\mathrm{e} \\
1.84 \mathrm{c}-\mathrm{e} \\
1.56 \mathrm{e}\end{array}$ & $\begin{array}{l}1.8 \mathrm{c}-\mathrm{e} \\
2.21 \mathrm{a}-\mathrm{c} \\
2.07 \mathrm{a}-\mathrm{c} \\
1.72 \mathrm{~cd}\end{array}$ & $\begin{array}{c}1.76 \mathrm{de} \\
2.78 \mathrm{a} \\
2.68 \mathrm{ab} \\
1.56 \mathrm{e}\end{array}$ & $\begin{array}{c}1.74 \mathrm{de} \\
2.53 \mathrm{ab} \\
2.37 \mathrm{ab} \\
1.53 \mathrm{e}\end{array}$ & $\begin{array}{l}1.7 \mathrm{~B} \\
2.36 \mathrm{~A} \\
2.22 \mathrm{~A} \\
1.59 \mathrm{~B}\end{array}$ \\
\hline Mean & $1.7 \mathrm{~B}$ & $1.95 \mathrm{AB}$ & $2.18 \mathrm{~A}$ & $2.04 \mathrm{AB}$ & \\
\hline \multicolumn{6}{|c|}{ Season 2015} \\
\hline $\begin{array}{l}\text { Non-pruning(control) } \\
\text { one-third removal } \\
\text { one-half removal } \\
\text { Whole branch removal }\end{array}$ & $\begin{array}{l}1.54 \mathrm{~d} \\
1.86 \mathrm{~cd} \\
1.79 \mathrm{~cd} \\
1.50 \mathrm{~d}\end{array}$ & $\begin{array}{l}1.73 \mathrm{de} \\
2.11 \mathrm{a}-\mathrm{c} \\
2.0 \mathrm{a}-\mathrm{c} \\
1.52 \mathrm{~d}\end{array}$ & $\begin{array}{c}1.7 \mathrm{~cd} \\
2.54 \mathrm{a} \\
2.27 \mathrm{a}-\mathrm{c} \\
1.59 \mathrm{~d}\end{array}$ & $\begin{array}{c}1.7 \mathrm{~cd} \\
2.47 \mathrm{ab} \\
2.13 \mathrm{a}-\mathrm{c} \\
1.62 \mathrm{~d}\end{array}$ & $\begin{array}{l}1.67 \mathrm{~B} \\
2.25 \mathrm{~A} \\
2.07 \mathrm{~A} \\
1.56 \mathrm{~B}\end{array}$ \\
\hline Mean & $1.67 \mathrm{~B}$ & $1.87 \mathrm{AB}$ & $2.03 \mathrm{~A}$ & 1.99A & \\
\hline
\end{tabular}

Values followed by the same letter (s) are not significantly different at $5 \%$ level

\section{Total yield (kg/tree)}

Data tabulated in Table (8) show the effect of different models of pruning and different type of coverage for levels on Total yield ( $\mathrm{kg} / \mathrm{tree})$ on Kitt Mango Tree during 2014 and 2015 seasons.

There were significant differences clear increase in total yield of Mango Trees Kitt which has been the removal of one-third of branches, was trim by removing one third of the branches, which were trim by removing half of the branch or removing entire branches during the two study seasons.

Increasing the total yield of Mango Trees Kitt has covered the White plastic or straw through the seasons with a significant difference between them.

The highest values for interaction along with the level of the section was trim third section with a white plastic cover and lower values with the removal of entire branches with no coverage.

Table 8. Effect of pruning pattern and soil mulching type on total yield $(\mathrm{kg})$ of Kitt Mango Trees during 2014 and 2015 seasons.

\begin{tabular}{|c|c|c|c|c|c|}
\hline \multirow{3}{*}{ Pruning Treatments } & \multirow{2}{*}{\multicolumn{4}{|c|}{$\begin{array}{c}\text { Season } 2014 \\
\text { Soil mulching type }\end{array}$}} & \multirow[t]{3}{*}{ Mean } \\
\hline & & & & & \\
\hline & Without & Black & White & Rice Straw & \\
\hline $\begin{array}{l}\text { Non-pruning(control) } \\
\text { one-third removal } \\
\text { one-half removal } \\
\text { Whole branch removal }\end{array}$ & $\begin{array}{l}14.0 \mathrm{e} \\
14.3 \mathrm{e} \\
13.4 \mathrm{e} \\
13.8 \mathrm{e}\end{array}$ & $\begin{array}{c}14.8 \mathrm{de} \\
16.7 \mathrm{~b}-\mathrm{d} \\
14.8 \mathrm{de} \\
14.2 \mathrm{e}\end{array}$ & $\begin{array}{c}16.9 \mathrm{bc} \\
19.9 \mathrm{a} \\
18.8 \mathrm{ab} \\
15.2 \mathrm{c}-\mathrm{e}\end{array}$ & $\begin{array}{c}14.9 \mathrm{de} \\
17.8 \mathrm{ab} \\
17.3 \mathrm{~b} \\
15.0 \mathrm{c}-\mathrm{e}\end{array}$ & $\begin{array}{l}15.2 \mathrm{AB} \\
15.7 \mathrm{~A} \\
16.0 \mathrm{~A} \\
14.5 \mathrm{C}\end{array}$ \\
\hline Mean & $13.9 \mathrm{C}$ & $15.1 \mathrm{~B}$ & 17.7 A & $16.2 \mathrm{~B}$ & \\
\hline \multicolumn{6}{|c|}{ Season 2015} \\
\hline $\begin{array}{l}\text { Non-pruning(control) } \\
\text { one-third removal } \\
\text { one-half removal } \\
\text { Whole branch removal }\end{array}$ & $\begin{array}{c}13.1 \mathrm{e} \\
16.1 \mathrm{~cd} \\
14.7 \mathrm{de} \\
13.9 \mathrm{e}\end{array}$ & $\begin{array}{c}14.2 \mathrm{de} \\
18.1 \mathrm{bc} \\
16.3 \mathrm{c} \\
13.4 \mathrm{e}\end{array}$ & $\begin{array}{c}16.9 \mathrm{c} \\
20.7 \mathrm{a} \\
18.6 \mathrm{ab} \\
16.2 \mathrm{~cd}\end{array}$ & $\begin{array}{l}14.5 \mathrm{de} \\
19.6 \mathrm{ab} \\
17.7 \mathrm{bc} \\
14.8 \mathrm{de}\end{array}$ & $\begin{array}{l}14.7 \mathrm{C} \\
18.6 \mathrm{~A} \\
16.8 \mathrm{~B} \\
14.5 \mathrm{C}\end{array}$ \\
\hline Mean & $14.5 \mathrm{C}$ & $15.5 \mathrm{~B}$ & $18 \mathrm{~A}$ & $16.6 \mathrm{~B}$ & \\
\hline
\end{tabular}

Values followed by the same letter (s) are not significantly different at $5 \%$ level 


\section{Marketable yield \%}

Data tabulated in Table (9) show the effect of different models of pruning and different type of coverage for levels on Marketable yield \% on Kitt Mango Tree during 2014 and 2015 seasons.

There were significant differences clear increase in the proportion of marketable fruit to Mango Trees Kitt which has been the removal of one-third of branches, which has remove half the branches branch entire seasons during the study.

Increase the percentage of marketable fruit to Mango Trees Kitt has covered the White plastic or straw during the seasonal study with no significant differences.

The highest values for interaction along with the level of the section was trim third section with a white plastic cover and lower values with the removal of entire branches with no coverage.

The results were in agreements with those obtained by Wolfram et al (2008). on yield and fruit development in mango (Mangifera indica L. cv. Chok Anan) under different irrigation regimes and Sarker and Rahim (2012). Vegetative growth, harvesting time, yield and quality of mango (Mangifera indica L.) as influenced by soil drench application of Paclobutrazol.

\section{Chemical fruit constituents SSC \%}

Data tabulated in Table (10) show the effect of different models of pruning and different type of coverage for levels on SSC\% on Kitt Mango Tree during 2014 and 2015 seasons.

Table 9. Effect of pruning pattern and soil mulching type on marketable yied \% of Kitt Mango trees during 2014 and 2015 seasons

\begin{tabular}{|c|c|c|c|c|c|}
\hline \multirow{3}{*}{ Pruning Treatments } & \multicolumn{4}{|c|}{ Season 2014} & \multirow{3}{*}{ Mean } \\
\hline & \multicolumn{4}{|c|}{ Soil mulching type } & \\
\hline & Without & Black & White & Rice Straw & \\
\hline $\begin{array}{l}\text { Non-pruning(control) } \\
\text { one-third removal } \\
\text { one-half removal } \\
\text { Whole branch removal }\end{array}$ & $\begin{array}{l}75.9 \mathrm{c} \\
76.8 \mathrm{c} \\
76.8 \mathrm{c} \\
74.5 \mathrm{c}\end{array}$ & $\begin{array}{c}77.1 \mathrm{c} \\
88.0 \mathrm{ab} \\
83.9 \mathrm{a}-\mathrm{c} \\
75.9 \mathrm{c} \\
\end{array}$ & $\begin{array}{c}80.2 \mathrm{bc} \\
93.2 \mathrm{a} \\
89.8 \mathrm{ab} \\
76.5 \mathrm{c}\end{array}$ & $\begin{array}{l}80.8 \mathrm{bc} \\
89.2 \mathrm{ab} \\
85.6 \mathrm{ab} \\
77.0 \mathrm{c}\end{array}$ & $\begin{array}{c}\text { 78.5 C } \\
\text { 86.8 A } \\
\text { 84.1 AB } \\
76.0 \mathrm{C} \\
\end{array}$ \\
\hline Mean & $76.0 \mathrm{~B}$ & $81.2 \mathrm{~A}$ & $85.0 \mathrm{~A}$ & 83.1 A & \\
\hline \multicolumn{6}{|c|}{ Season 2015} \\
\hline $\begin{array}{l}\text { Non-pruning(control) } \\
\text { one-third removal } \\
\text { one-half removal } \\
\text { Whole branch removal }\end{array}$ & $\begin{array}{l}75.4 \mathrm{~cd} \\
79.8 \mathrm{~b}-\mathrm{d} \\
78.5 \mathrm{~cd} \\
74.6 \mathrm{~d}\end{array}$ & $\begin{array}{l}81.0 \mathrm{~b}-\mathrm{d} \\
84.4 \mathrm{a}-\mathrm{c} \\
84.0 \mathrm{a}-\mathrm{c} \\
75.5 \mathrm{~cd}\end{array}$ & $\begin{array}{l}89.8 \mathrm{ab} \\
93.5 \mathrm{a} \\
85.7 \mathrm{~cd} \\
78.7 \mathrm{~cd}\end{array}$ & $\begin{array}{l}81.2 \mathrm{~b}-\mathrm{d} \\
89.4 \mathrm{ab} \\
84.8 \mathrm{a}-\mathrm{c} \\
75.6 \mathrm{ed}\end{array}$ & $\begin{array}{c}\text { 81.9 BC } \\
86.8 \mathrm{~A} \\
83.2 \mathrm{AB} \\
67.0 \mathrm{C}\end{array}$ \\
\hline Mean & $77.0 \mathrm{C}$ & $81.2 \mathrm{~B}$ & $86.8 \mathrm{~A}$ & 82.7 AB & \\
\hline
\end{tabular}

Values followed by the same letter (s) are not significantly different at $5 \%$ level

Table 10. Effect of pruning pattern and soil mulching type on SSC\% of Kitt Mango Trees during 2014 and 2015 seasons.

\begin{tabular}{|c|c|c|c|c|c|}
\hline \multirow{3}{*}{ Pruning Treatments } & \multicolumn{4}{|c|}{ Season 2014} & \multirow{3}{*}{ Mean } \\
\hline & \multicolumn{4}{|c|}{ Soil mulching type } & \\
\hline & Without & Black & White & Rice Straw & \\
\hline Non-pruning(control) & $16.2 \mathrm{~cd}$ & $16.5 \mathrm{~cd}$ & $17.0 \mathrm{c}$ & $17.3 \mathrm{c}$ & $16.8 \mathrm{~B}$ \\
\hline one-third removal & $16.7 \mathrm{~cd}$ & $18.0 \mathrm{bc}$ & $19.4 \mathrm{a}$ & $18.6 a b$ & $18.2 \mathrm{~A}$ \\
\hline one-half removal & $16.2 \mathrm{~cd}$ & $17.3 \mathrm{c}$ & $18.2 \mathrm{bc}$ & $17.5 \mathrm{bc}$ & 17.3 AB \\
\hline Whole branch removal & $15.6 \mathrm{~d}$ & $16.0 \mathrm{~d}$ & $16.7 \mathrm{~cd}$ & $17.0 \mathrm{c}$ & 16.3 B \\
\hline Mean & 16.2 B & 17.0 AB & $17.8 \mathrm{~A}$ & $17.6 \mathrm{~A}$ & \\
\hline \multicolumn{6}{|c|}{ Season 2015} \\
\hline Non-pruning(control) & $16.0 \mathrm{~d}$ & $16.3 d$ & $17.4 \mathrm{bc}$ & $17.1 \mathrm{~cd}$ & 16.7 BC \\
\hline one-third removal & $17.0 \mathrm{~cd}$ & $18.3 \mathrm{bc}$ & $19.0 \mathrm{a}$ & $19.1 \mathrm{a}$ & $18.4 \mathrm{~A}$ \\
\hline one-half removal & $16.5 \mathrm{~d}$ & $17.0 \mathrm{~cd}$ & $18.5 a b$ & $17.9 \mathrm{bc}$ & $17.5 \mathrm{~B}$ \\
\hline Whole branch removal & $15.8 \mathrm{~d}$ & $15.9 \mathrm{~d}$ & $16.5 \mathrm{~d}$ & $17.2 \mathrm{~cd}$ & $16.2 \mathrm{C}$ \\
\hline Mean & $16.2 \mathrm{~B}$ & $16.9 \mathrm{~B}$ & $17.9 \mathrm{~A}$ & $17.8 \mathrm{~A}$ & \\
\hline
\end{tabular}

Values followed by the same letter (s) are not significantly different at $5 \%$ level 
There were significant differences evident in the increase in soluble solids of mango trees that have been Mango Trees Kitt the removal of onethird of branches, which has to remove half of the branch branches during the entire seasons of study.

Increase the proportion of dissolved solids to Mango trees Kitt has covered the White plastic or straw during the seasonal study with no significant differences.

The highest values for interaction along with the level of the section was trim third section with a white plastic cover and lower values with the removal of entire branches with no coverage.

\section{Total acidity \% (g citric acid/ $100 \mathrm{~g}$ fruit flesh).}

Data tabulated in Table (11) show the effect of different models of pruning and different type of coverage for levels on Total acidity \% \% on Kitt Mango Tree during 2014 and 2015 seasons.
There were significant differences evident in the total acidity of mango trees that have been Mango Trees Kitt the removal of one-third of branches, which has to remove half of the branch branches during the entire study, the proportion of seasons.

There are no significant differences for total acidity of Mango Trees Kitt, which has covered the White plastic or straw through the seasons.

The highest values for interaction along with the level of the section was trim third section with a white plastic cover and lower values with the removal of entire branches with no coverage.

\section{L-ascorbic acid (mg/100 $\mathrm{g}$ fruit flesh}

Data tabulated in Table (12) show the effect of different models of pruning and different type of coverage for levels on L-ascorbic acid on Kitt Mango Tree during 2014 and 2015 seasons.

Table 11. Effect of pruning pattern and soil mulching type on titratable acidity \% of Kitt Mango trees during 2014 and 2015 seasons

\begin{tabular}{|c|c|c|c|c|c|}
\hline \multirow{3}{*}{ Pruning Treatments } & \multicolumn{4}{|c|}{ Season 2014} & Mean \\
\hline & \multicolumn{4}{|c|}{ Soil mulching type } & \\
\hline & Without & Black & White & Rice Straw & \\
\hline Non-pruning(control) & $0.61 \mathrm{a}$ & $0.50 \mathrm{~b}-\mathrm{d}$ & $052 a b c$ & $0.54 a b$ & $0.54 \mathrm{AB}$ \\
\hline one-third removal & $0.57 \mathrm{ab}$ & $0.42 \mathrm{~cd}$ & $0.43 \mathrm{~cd}$ & $0.40 \mathrm{~d}$ & $0.46 \mathrm{C}$ \\
\hline one-half removal & $0.6 \mathrm{a}$ & $0.46 \mathrm{~cd}$ & $0.46 \mathrm{~cd}$ & $0.47 \mathrm{~b}-\mathrm{d}$ & $0.50 \mathrm{BC}$ \\
\hline Whole branch removal & $0.62 a$ & $0.54 \mathrm{ab}$ & $0.43 \mathrm{a}-\mathrm{c}$ & $0.57 a b$ & $0.57 \mathrm{~A}$ \\
\hline Mean & $0.6 \mathrm{~A}$ & $0.48 \mathrm{~B}$ & $0.49 \mathrm{~B}$ & $0.50 \mathrm{~B}$ & \\
\hline \multicolumn{6}{|c|}{ Season 2015} \\
\hline Non-pruning(control) & $0.52 a b$ & $0.50 a-c$ & $0.49 a-c$ & $0.48 \mathrm{a}-\mathrm{c}$ & $0.52 \mathrm{~A}$ \\
\hline one-third removal & $0.53 \mathrm{a}$ & $0.40 \mathrm{~b}$ & $0.41 \mathrm{c}$ & $0.40 \mathrm{c}$ & $0.44 \mathrm{~B}$ \\
\hline one-half removal & $0.53 \mathrm{a}$ & $0.50 \mathrm{a}-\mathrm{c}$ & $0.47 \mathrm{a}-\mathrm{c}$ & $0.43 \mathrm{bc}$ & $0.48 \mathrm{AB}$ \\
\hline Whole branch removal & $0.56 \mathrm{a}$ & $0.52 a b$ & $0.50 \mathrm{abc}$ & $0.50 \mathrm{a}-\mathrm{c}$ & $0.53 \mathrm{~A}$ \\
\hline Mean & $0.55 \mathrm{~A}$ & $0.49 \mathrm{~B}$ & $0.48 \mathrm{~B}$ & $0.45 \mathrm{~B}$ & \\
\hline
\end{tabular}

Values followed by the same letter (s) are not significantly different at $5 \%$ level 
Table 12. Effect of pruning pattern and soil mulching type on $\mathrm{L}$-ascorbic acid content (mg for $1000 \mathrm{~g}$ fresh weight) of Kitt Mango trees during 2014 and 2015 seasons.

\begin{tabular}{|c|c|c|c|c|c|}
\hline \multirow{3}{*}{ Pruning Treatments } & \multicolumn{4}{|c|}{ Season 2014} & \multirow{3}{*}{ Mean } \\
\hline & \multicolumn{4}{|c|}{ Soil mulching type } & \\
\hline & Without & Black & White & Rice Straw & \\
\hline $\begin{array}{l}\text { Non-pruning(control) } \\
\text { one-third removal } \\
\text { one-half removal } \\
\text { Whole branch removal }\end{array}$ & $\begin{array}{l}34.2 \mathrm{e} \\
37.1 \mathrm{~d} \\
35.8 \mathrm{e} \\
34.8 \mathrm{e}\end{array}$ & $\begin{array}{c}36.5 \mathrm{de} \\
42.7 \mathrm{ab} \\
40.8 \mathrm{~b} \\
38.5 \mathrm{~cd}\end{array}$ & $\begin{array}{c}39.7 \mathrm{bc} \\
46.7 \mathrm{a} \\
43.1 \mathrm{ab} \\
38.5 \mathrm{~cd}\end{array}$ & $\begin{array}{c}37.2 \mathrm{~d} \\
43.2 \mathrm{ab} \\
40.2 \mathrm{bc} \\
37.1 \mathrm{~d}\end{array}$ & $\begin{array}{l}\text { 36.9 B } \\
42.2 \mathrm{~A} \\
40.0 \mathrm{~A} \\
37.2 \mathrm{~B}\end{array}$ \\
\hline Mean & $35.5 \mathrm{C}$ & $39.6 \mathrm{~B}$ & $42.0 \mathrm{~A}$ & $39.4 \mathrm{~B}$ & \\
\hline \multicolumn{6}{|c|}{ Season 2015} \\
\hline $\begin{array}{l}\text { Non-pruning(control) } \\
\text { one-third removal } \\
\text { one-half removal } \\
\text { Whole branch removal }\end{array}$ & $\begin{array}{l}37.2 \mathrm{~d} \\
36.7 \mathrm{~d} \\
37.1 \mathrm{~d} \\
36.9 \mathrm{~d}\end{array}$ & $\begin{array}{l}39.6 \mathrm{~b}-\mathrm{d} \\
44.7 \mathrm{a} \\
42.9 \mathrm{ab} \\
37.1 \mathrm{~cd}\end{array}$ & $\begin{array}{l}40.7 \mathrm{bc} \\
40.5 \mathrm{a} \\
40.2 \mathrm{bc} \\
39.0 \mathrm{~cd}\end{array}$ & $\begin{array}{l}41.2 \mathrm{a}-\mathrm{c} \\
43.8 \mathrm{ab} \\
42.1 \mathrm{ab} \\
40.1 \mathrm{bc}\end{array}$ & $\begin{array}{c}40.0 \mathrm{AB} \\
41.8 \mathrm{~A} \\
40.6 \mathrm{AB} \\
38.5 \mathrm{~B}\end{array}$ \\
\hline Mean & $37.0 \mathrm{~B}$ & $41.3 \mathrm{~A}$ & 41.3 A & 41.8 A & \\
\hline
\end{tabular}

Values followed by the same letter (s) are not significantly different at $5 \%$ level

There were significant differences evident in ascorbic acid to Mango trees Kitt which were trim by removing one third of the branches, which were trim by removing half of the branch or removing entire branches during the two study seasons.

There are significant differences in ascorbic acid to Mango Trees Kitt that have been covered with plastic White or straw during the season's ratio.

The highest values for interaction along with the level of the section was trim third section with a white plastic cover and lower values with the removal of entire branches with no coverage.

The results were in agreements with those obtained by TANDEL AND L. PATEL 2011.on Effect of chemicals on growth, yield and economics of mango (Mangifera indica L.) and Shi, Ma et al (2015). Evaluation of 28 mango genotypes for physicochemical characters, antioxidant capacity, and mineral content.

\section{RECOMMENDATION}

The results obtained using white plastic in the coverage of the surface of the soil with the use of the process of pruning one of the branches to obtain of the high quality and abundant production, where the impact of white plastic to improve the quality of mango fruits and the pruning of one-third of the branch was positive in increasing the number of fruiting branches of kitt mango trees.

\section{REFERENCES}

A.O.A.C. 1980. Official Methods of Analysis, $13^{\text {th }}$ ed. Association of Official Analytical Chemists Washington D.C., USA, pp. 376-384
Abdel-Aziz, R.A., Sabri M.A. and Al-Bitar L., 2010. Impact of some soil mulch treatments on tree growth, yield, fruit quality and storability of valencia orange under Toshka conditions. Zagazig J. of Agric. Res., 37(1), 57-79.

Adak, T., Kumar K. and Singha A., 2012. Spatiotemporal variations in soil moisture and soil temperature under high density guava orchard system. In: Proceedings of $5^{\text {th }}$ Indian Horticulture Congress on Horticulture for Food and Environment Security held during November 6-9, at PAU, Ludhiana, India. 397 p.

Albiach, R., Canet, R., Pomares, F. and Ingelmo F. 2000. Microbial biomass content and enzymatic activities after the application of organic amendments to a horticultural soil. Biores. Technol. 75, 43-48.

Arancon, N.Q., Edwars, C.A. and Bierman, P. 2006. Influences of vermicomposts on field strawberries: 2. Effects on soil microbiological and chemical properties. Bioresour. Technol. 97, 831-840.

Babul C. Sarker and Rahim, M.A. 2012. Vegetative growth, harvesting time, yield and quality of mango (Mangifera indica L.) as influenced by soil drench application of Paclobutrazol. Bangladesh J. Agril. Res. 37(2), 335-348.

Bell, C.W., McIntyre, N.E., Cox, S.B., Tissue, D.T. and Zak, J.C. 2008. Soil microbial responses to temporal variations of moisture and temperature in a Chihuahuan Deser grassland. Microb. Ecol., 56, 153-167.

Bulluck, L.R., Brosius, M., Evanoylo, G.K. and Ristaino, J.B. 2002. Organic and synthetic fer- 
tility amendments influence soil microbial, physical and chemical properties on organic and conventional farms. Appl. Soil Ecol. 19, 147-160.

Bompard, J.M. 1993. The genus Mangifera rediscovered: The potential contribution of wild species to mango cultivation. Acta Hort., Leuven, Belgium 341, 69-71.

Bremner, J.M. and Mulvaney, C.S. 1982. "Total nitrogen", In: A.L. Page, R.H. Miller and D.R Keeny, (Eds.), Methods of Soil Analysis, $2^{\text {nd }}$ Edition, Agronomy Monograph 9, 595-624.

Ferreras, L., Gómez, E., Toresani, S., Firpo, L. and Rotondo, R. 2006. Effect of organic amendments on some physical, chemical and biological properties in a horticultural soil. Bioresour.Technol. 97, 635-640.

Economic Agric., Report 2015. From Central Administration for Economic Agric., Ministry of Agric., Egypt, 201(5), Part 2, 282 p.

Evenhuis B. and Dewaard P.W. 1980. Principles and practices in plant analysis. FAO. Soil Bull., 38(1), 1152-1163.

Gaikwad, S.C., Ingle, H.V., Panchbhai, D.M. and Ingle, S.H. 2004. Effect of different types of mulches on soil moisture, soil temperature and fruit drop in nagpur mandarin. Agric. Sci. Digest, 24(1), 71-72.

Hazarika, S., Ganeshamurthy, A.N. and Sakthivel, T. 2011. Long-term management effects on spatial variability of quality characteristics of soils under guava (Psidium guajava) and sapota (Manilkara achras) orchards in southwestern climate of India. Indian J. Agric. Sci. 81, 119-124.

Kumar., 2012. Effect of bio-organic and inorganic nutrient sources to improve leaf nutrient status in apricot. Indian J. of Hort., 69(1), 45-49.

Mukherjee, S.K., 1985. The origin of mango. Indian J. Hort., 15,129-134.

Mikhael, G.B. 2007. Effect of some drip irrigation and mulching treatments on: 1 . vegetative growth and nutritional status of "anna" apple trees grown in new reclaimed soils. Minufiya $\mathbf{J}$. Agric. Res. 32 (4), 1155-1174.

Nijjar, G.S. 1985. Nutrition of fruit-trees. Published by Kaylyani, publishers, New Delhi, India. 117, (1), 39-44
Dutta, P., Ahmed, B. and Kundu, S. 2011. Effect of Different Sources of Potassium on Yield, Quality, and Leaf Mineral Content of Mango in West Bengal.

Ruck, J.A. 1969. Chemical Methods for Analysis of Fruit and Vegetables, pp: 27-30. Summerland Res. State,Department of Agriculture, Canada.

Shi, S., Ma, X., Xu, W., Zhou, Y., Wu, H. and Wang, S. 2015. Evaluation of 28 mango genotypes for physicochemical characters, antioxidant capacity, and mineral content. J. of Applied Botany and Food Quality 88, 264 273.

Singh, A.K., Singh, S. and Appa Rao, V.V. 2012. Influence of organic and inorganic nutrient sources on soil properties and quality of Aonla in hot semi-arid ecosystem. Indian J. of Hort., 69(1), 50- 54.

Singh, V.J., Somdev, S., Pramod, K. and Satish, B. 2011. Soil Science Society of America, Madison, pp. 1119-1123.

Snedecor , G.W. and Cochron, W.G. 1980 Statistical Methods $5^{\text {th }}$ pp.5-7 Ed. lowa Univ., Press Amer. lowa, USA,

Tomas A., Reed S., Dunn, C. and Gozlekci, S. 2012. Minerals and Metal Content of Four Mango (Mangifera indica L.) Cultivar Leaves Grown in South Florida, Poster Board

Tejada, M., Hernández, M.T. and García, C. 2006. Application of two organic amendments on soil restoration: Effects on the soil biological properties. J. Environ. Qual. 35, 1010-1017.

Tandel, Y.N. and Patel, N.L. 2011. Effect of chemicals on growth, yield and economics of mango (Mangifera indica L.) Regional Hort. Research Station, ASPEE College of Horticulture and Forestry Navsari Agric. Univ. Navsari, 396 450, India.

Wilde, S.A., Cory, R.B., Lyer, J.G. and Voigt, G.K. 1985. Soils and Plants Analysis for Tree Cultures. pp. 94-105. OxforlBH, New Delhi, India.

Wolfram Spreer, Ongprasert S., Hegele M., Wu" nsche J.N. and Mu" Iler J. 2008. Yield and fruit development in mango (Mangifera indica L. Cv. Chok Anan) under different irrigation regimes. University of Hohenheim Agric. Water Management 96, 574-584. 